\title{
Management Information from Data Bases
}

\section{T. Crowe}

Thames Polytechnic

D. E. Avison

University of Aston in Birmingham

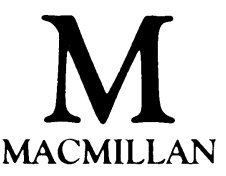


(C) T Crowe and D. E. Avison 1980

All rights reserved. No reproduction, copy or transmission of this publication may be made without written permission.

No paragraph of this publication may be reproduced, copied or transmitted save with written permission or in accordance with the provisions of the Copyright Act 1956 (as amended).

Any person who does any unauthorised act in relation to this publication may be liable to criminal prosecution and civil claims for damages.

First published 1980

Reprinted 1982, 1985

Published by

MACMILLAN EDUCATION LTD

Houndmills, Basingstoke, Hampshire RG21 2XS

and London

Companies and representatives

throughout the world

ISBN 978-0-333-26085-2 ISBN 978-1-349-16344-1 (eBook)

DOI $10.1007 / 978-1-349-16344-1$

To Marie-Anne

and Pauline

The paperback edition of this book is sold subject to the condition that it shall not, by way of trade or otherwise, be lent, resold, hired out, or otherwise circulated without the publisher's prior consent in any form of binding or cover other than that in which it is published and without a similar condition including this condition being imposed on the subsequent purchaser. 


\title{
Contents
}

\author{
Preface
}

1 The Growth and Development of Information Systems

1.1 Introduction

1.2 The Expanded Use of Computers

1.3 The Need for a Positive Methodology

1.4 Current Trends in Systems Theory

1.5 The Involvement of Management

1.6 Historical Development, Automation of the Clerical Process

1.7 Information in Organisations

1.8 The Alienation

1.9 A Methodology

1.10 The Way Ahead

2 Systems Theory and the Organisation

2.1 Introduction

2.2 The Systems Concept

2.3 A Hierarchy of Systems

2.4 Closed and Open Systems

2.5 The Systems Approach versus the Disciplinary Approach

2.6 Optimal versus Practical

2.7 The Information Requirements of an Organisation

2.8 Criteria for Management Information Systems Design

2.9 Pitfalls in the Design of the MIS

3 Strategies for MIS Design

3.1 Introduction

3.2 The Systems Planning Team

3.3 The Terms of Reference for the Systems Planning Team

3.4 The Position of the Systems Planning Team in the Organisation

3.5 Membership of the Systems Planning Team 36

3.6 Design Review 
3.7 The Boundaries of the System 39

3.8 Strategies for MIS Design 40

3.9 Management as the Basis of MIS 48

3.10 Word Processing 51

4 Modelling the Organisation - A Schematic Approach

4.1 The Overall Methodology - A Perspective 52

4.2 Data Analysis $\quad 56$

4.3 Conceptual Schema 60

4. 4 Logical Schema 63

4.5 A Methodology to Formulate the Logical Schema 66

4.6 Organising the Logical Scherna 73

$\begin{array}{ll}4.7 \text { Physical Schema } & 73\end{array}$

$\begin{array}{ll}\text { Case History } & 79\end{array}$

5 Implementation of the MIS - Project Development and Control

5.1 Introduction 86

5.2 The Overall Plan 87

5.3 The Implementation Priority of Subsystems 88

5.4 An Implementation Scheme for Subsystems 92

5.5 Preliminary Analysis 92

5.6 The Feasibility Assessment 93

5.7 Detailed Fact-finding 93

5.8 Systems Analysis 94

5.9 Systems Design 95

5.10 Systems Development 95

5.11 Cutover 96

5.12 Review 96

5.13 Project Control Techniques 97

6 Information Technology
6.1 Introduction

6.2 Terminals 103

6.3 Data Transmission Facilities 107

$\begin{array}{ll}6.4 \text { Networks } & 110\end{array}$

6.5 Data Bases 112

6.6 Word Processing 115

6.7 Consequences of the Technology 118

7 Introduction to Data Base Management
7.1 Introduction

7.2 Evolution of the Data Base 122

7.3 Limitations of the Conventional (Non Data
Base) Approach

$\begin{array}{ll}7.4 \text { Defining the Modern Data Base } & 125\end{array}$ 


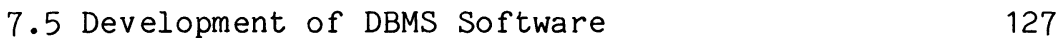

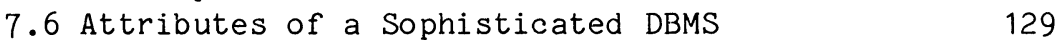

8 The Nature of Data

8.1 Introduction

8.2 The Data Model 137

8.3 Validation of Queries 142

8.4 The Natural Size for Data Bases? 144

8.5 Distributed Data Bases 151

8.6 Theory of Discourse 151

8.7 Conclusion

9 The Cost of Information

9.1 Introduction

9.2 Traditional Cost Justification 155

9.3 Approaches to the Problem 162

9.4 The Boundaries of MIS 164

9.5 The Qualitative Value of Information 166

9.6 The Modeling of Information Systems 166

9.7 Theoretical Approaches to the Problem 169

9.8 Conclusion 174

10 Human and Social Implications of MIS

10.1 The People Problem 175

10.2 Maslow's Hierarchy of Needs 176

10.3 Dysfunctional Behaviour - A Reaction to 177

10.4 Reaction against Computer Systems 180

10.5 Affecting the Attitudes of Employees 182

10.6 Top Management Involvement 183

10.7 Improved Communication and User Participation 183

10.8 Planned Approach to Change 185

$\begin{array}{ll}10.9 \text { Society and MIS } & 185\end{array}$

$\begin{array}{ll}\text { Appendix A - The Case Study } & 190\end{array}$

Appendix B - TV Rental Operational Control 195

$\begin{array}{lr}\text { Ind ex } & 197\end{array}$ 


\section{Preface}

This book is the product of many years of teaching management students about the role of the computer in supporting the function of management in both the public and private sectors. It assumes that its readers are, in the main, managers or management students. It is essential that managers become familiar with this growth area of management practice and participate in the making of any changes associated with the computer.

Although not necessarily computer experts, readers are assumed to be familiar with computers at least to the extent that they have completed a short introduction to computer data processing' course. The book should also be useful to data processing professionals and the material has been used in a B.Sc. Computer Science course because the systems development staff need to understand the overall problems and methodology of management information systems (MIS). For the purposes of computer scientists, however, it will need to be supplemented with a more technical text.

The book aims to be both practical and topical. It puts forward a methodology for the development and implementation of MIS. It presents the material in a way that is as non-theoretical as possible and many examples are discussed so as to emphasise the practical nature of its contents. This subject needs to be taught using case studies and a major case study is given in appendix A. Case histories, which are drawn from practical experience, are discussed in the body of the text. It is the author' ' experience that students who follow the case study find that it supports the subject of the text by bringing out and reinforcing the major problems of developing a MIS.

Chapter 1 attempts to set the scene. It explores the involvement of management in guiding the rapid evolution of computer-based information systems so that the changeover will be smooth and the results serve the needs of managers and not those of the computer. 
A methodology for the implementation of MIS is covered in chapters 2, 3, 4 and 5 together with a case study described in appendix A. The systems viewpoint is discussed in chapter 2 and to make a useful contribution to the methodology the practical aspects of systems theory are emphasised. Chapter 3 shows how a systems planning team can develop a strategy for design and take a view of data that will give management the information they want to control resources.

An overview of the methodology put forward in the book is introduced in chapter 4 and figure 4.1, which expresses this overall methodology, is likely to be referred to throughout the book. The chapter then looks at data analysis, which is part of this methodology. Data analysis will produce a data model of the organisation which will then become the data base from which the information requirements of the organisation can be satisfied. Chapter 5 shows how the MIS is developed and implemented. It discusses how the overall system may be conveniently broken up into interconnected parts called subsystems and how each of these is implemented. Analysing the requirements of the new subsystem, which will precede its implementation, is referred to as functional analysis.

The remaining chapters provide support material essential for an understanding of the implementation problems. Chapter 6 surveys recent technical developments that will have an impact on MIS. It concentrates on those developments that are particularly relevant to the manager; indeed, he will need to understand these aspects in order to use the MIS to his best advantage. Data bases are discussed in chapter 7 , and emphasis is placed on the role of the data base administrator who will have overall responsibility for the management of the data base. Chapter 8 looks at the nature of data and its validation. The accuracy of the data in the data base is vital in an environment where each element of data may encounter many different users.

The difficult problem of the cost of information receives treatment in chapter 9. A balance is struck between an excessively quantitative approach and a 'laissez-faire' attitude towards the high costs involved in MIS development. Finally, human problems associated with change are discussed. If management fails to gain the cooperation of those involved, then the technology will also fail. These behavioural considerations are discussed in chapter 10 along with the wider social impact of MIS. 
PREFACE

We would like to thank both staff and students of Thames Polytechnic and the University of Aston who have, knowingly or unknowingly, made a contribution to this book. Particular mention should be made of Trevor Wood-Harper, Christine Blundell and Colin Barrow who were helpful in their specialist fields. A grateful thanks to Graham Smith for his work in producing the diagrams and Stella Mayes Reed for the photographs. 